\title{
SYNGAS AND HDS CATALYSTS DERIVED FROM SULPHIDO BIMETALLIC CLUSTERS
}

\author{
M. DAVID CURTIS,* JAMES E. PENNER-HAHN, JOHANNES SCHWANK, \\ OSWALDO BARALT, DANIEL J. McCABE, LEVI THOMPSON and \\ GEOFFREY WALDO
}

Departments of Chemistry and Chemical Engineering, The University of Michigan, Ann Arbor, MI 48109-1055, U.S.A.

\begin{abstract}
The clusters, $\mathrm{Cp}_{2}^{\prime} \mathrm{Mo}_{2} \mathrm{Fe}_{2} \mathrm{~S}_{2}(\mathrm{CO})_{8}$ (MoFeS) and $\mathrm{Cp}_{2}^{\prime} \mathrm{Mo}_{2} \mathrm{Co}_{2} \mathrm{~S}_{3}(\mathrm{CO})_{4}(\mathrm{MoCoS})$ $\left(\mathrm{Cp}^{\prime}=\eta-\mathrm{C}_{5} \mathrm{H}_{4} \mathrm{Me}\right)$ have been supported on the refractory oxides, $\mathrm{Al}_{2} \mathrm{O}_{3}, \mathrm{SiO}_{2}, \mathrm{TiO}_{2}$, and $\mathrm{MgO}$, and subjected to temperature programmed decomposition (TPDE) under flowing $\mathrm{H}_{2}$. Typically, $\mathrm{CO}$ evolution commences near $100^{\circ} \mathrm{C}$, followed by evolution of $1-2 \mathrm{Cp}-$ ligands from 180 to $400^{\circ} \mathrm{C}$ along with small amounts of $\mathrm{CO}_{2}, \mathrm{CH}_{4}$, and $\mathrm{H}_{2} \mathrm{~S}$ or $\mathrm{Me}_{2} \mathrm{~S}$. The resulting compositions are shown to be active catalysts for $\mathrm{CO}$ hydrogenation and hydrodesulphurization (HDS) of thiophene. Methane is the principal hydrocarbon product from $\mathrm{CO}$ hydrogenation except for $\mathrm{MoFeS} / \mathrm{MgO}$ where high selectivity for $\mathrm{C}_{2}$ products was observed. The activity and selectivity of $\mathrm{MoCoS} / \mathrm{Al}_{2} \mathrm{O}_{3}$ for thiophene HDS closely resembles those of conventionally prepared "cobalt molybdate" catalysts. The cluster derived catalysts have been characterized by Mössbauer and X-ray absorption (XANES and EXAFS) spectroscopies. It is concluded that the clusters undergo oxidation by the surface upon loss of organic ligands.
\end{abstract}

Over the last decade, there has been growing interest in organometallic compounds supported on refractory oxides as catalysts for a variety of reactions, including partial oxidations, ${ }^{1,2}$ olefin metathesis, ${ }^{3}$ hydrogenolysis and hydrogenation, ${ }^{4}$ carbonylation of nitro arenes, ${ }^{5}$ hydroformylation, ${ }^{6}$ and Fischer-Tropsch chemistry. ${ }^{7-14}$ This interest is derived in part from the perception that catalysts with unusual selectivities may be produced from organometallic precursors, especially bimetallic clusters.

What are the advantages, if any, of using organometallic catalyst precursors? From the standpoint of thermodynamics, one may argue that for a given support (and here a dehydroxylated support is quite different from the hydroxylated form), for a given reactant composition and pressure, and for a given concentration of supported metal species, there is a macro-state of lowest chemical potential. One might expect (naively) no difference, then, in behaviour between catalysts prepared by starting with metals in a low oxidation state (organometallics) or by starting with metals in a high oxidation state (conventional preparation). The former will be

\footnotetext{
* Author to whom correspondence should be addressed.
}

oxidized and the latter reduced under reaction conditions such that the final state will be the same for both catalysts.

This analysis neglects the kinetics of the surface reactions and the mobility (or lack thereof) of the surface species. In actual practice, the surface species may be trapped in metastable states which differ depending on the initial conditions. Furthermore, the actual compositions, and hence final states, also depend on the initial conditions. For example, the decomposition of metal carbonyls may lead to the formation of mctal carbides, whereas the counter ion $\left(\mathrm{Cl}^{-}, \mathrm{NO}_{3}^{-}, \mathrm{SO}_{4}^{2-}\right.$, etc.) of a high valent metal salt is also adsorbed on the surface during conventional preparative methods, and these counterions may affect the acidity of the support and the mobility of the metal species.

The answer to the question, "why use metal clusters?", is that one hopes to produce metastable states with desired selectivity which are not accessible from the conventional impregnation/ reduction approach. The use of organometallic clusters as catalyst precursors has an additional advantage over conventional approaches, especially in the formation of bimetallic catalysts. Namely, 
the surface of bimetallic cluster-derived catalysts is much more uniform than those prepared by sequential- or co-impregnation methods because the two metals are deposited together in a welldefined spatial array and in relative amounts defined by the cluster composition. Spectroscopic studies of the active site are greatly facilitated when the surface is uniform.

This paper reports the preparation and characterization of catalysts derived from the bimetallic clusters, $\mathrm{Cp}_{2}^{\prime} \mathrm{Mo}_{2} \mathrm{Fe}_{2} \mathrm{~S}_{2}(\mathrm{CO})_{8}$ ("MoFeS") and $\mathrm{Cp}_{2}^{\prime} \mathrm{Mo}_{2} \mathrm{Co}_{2} \mathrm{~S}_{3}(\mathrm{CO})_{4} \quad$ ("MoCoS"), $\quad\left(\mathrm{Cp}^{\prime}=\eta\right.$ $\mathrm{C}_{5} \mathrm{H}_{4} \mathrm{Me}$ ) whose structures are shown below.

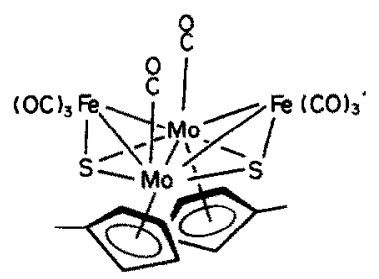

\section{EXPERIMENTAL}

The clusters were synthesized as described previously, ${ }^{15}$ and deposited on the oxide supports by contacting a $\mathrm{CH}_{2} \mathrm{Cl}_{2}$ solution of the cluster with sufficient support (previously calcined to $500^{\circ} \mathrm{C}$ ) to give a $1 \mathrm{wt} \%$ total metal loading. Under these conditions, the cluster was completely absorbed and the solid was then collected by filtration and dried under vacuum at room temperature. On the $\mathrm{Al}_{2} \mathrm{O}_{3}$ $\left(250 \mathrm{~m}^{2} \mathrm{~g}^{-1}\right.$, a $1 \%$ loading corresponds to $\mathrm{ca} 8 \%$ monolayer coverage ( $c a 100 \AA$ between clusters).

TPDE was conducted under flowing $\mathrm{H}_{2}$ or $\mathrm{He}$ at $1 \mathrm{~atm}$. pressure in an all glass system. Evolved hydrocarbons were analysed by GC/FID while $\mathrm{CO}$, $\mathrm{CO}_{2}$, and $\mathrm{H}_{2} \mathrm{~S}$ were measured by GC/TCD.

$\mathrm{CO}$ hydrogenations were performed in a glasslined stainless steel differential flow reactor at $\mathrm{CO}: \mathrm{H}_{2}$ ratios of $3: 1$ to $1: 1$ and at pressures of 4 $11 \mathrm{~atm}$. Thiophene HDS reactions were performed in an all glass differential flow reactor with $2.8 \mathrm{~mol}$ $\%$ thiophene in $\mathrm{H}_{2}(1 \mathrm{~atm}$.) feed. Products were analysed as above and product identities checked by GC/MS.

\section{RESULTS AND DISCUSSION}

\section{A. TPDE}

Each combination of cluster plus support shows slightly different behaviour during TPDE. In all cases, a burst of $\mathrm{CO}$ is observed near $100^{\circ} \mathrm{C}$, followed by gradual loss of Cp-ligand starting near $180^{\circ} \mathrm{C}$. Small amounts of $\mathrm{H}_{2} \mathrm{~S}$ or $\mathrm{Me}_{2} \mathrm{~S}$ (never both),
$\mathrm{CO}_{2}$, and $\mathrm{CH}_{4}$ are also evolved at higher temperatures. Figures 1 and 2 are typical TPDE curves.

Table 1 lists the average surface composition, as determined from the TPDE results, after heating to $400^{\circ} \mathrm{C}$. These compositions are obtained by subtracting from the initial composition the total moles of $\mathrm{C}$ and $\mathrm{S}$ evolved during TPDE. Since surface hydroxyl groups may contribute to the evolved hydrogen- and oxygen-containing species, it is impossible to quantify the remaining hydrogen or oxygen by this method.

The res lts in Table 1 show that in some cases, considerable $\mathrm{CH}_{4}$ is evolved. This $\mathrm{CH}_{4}$ may arise
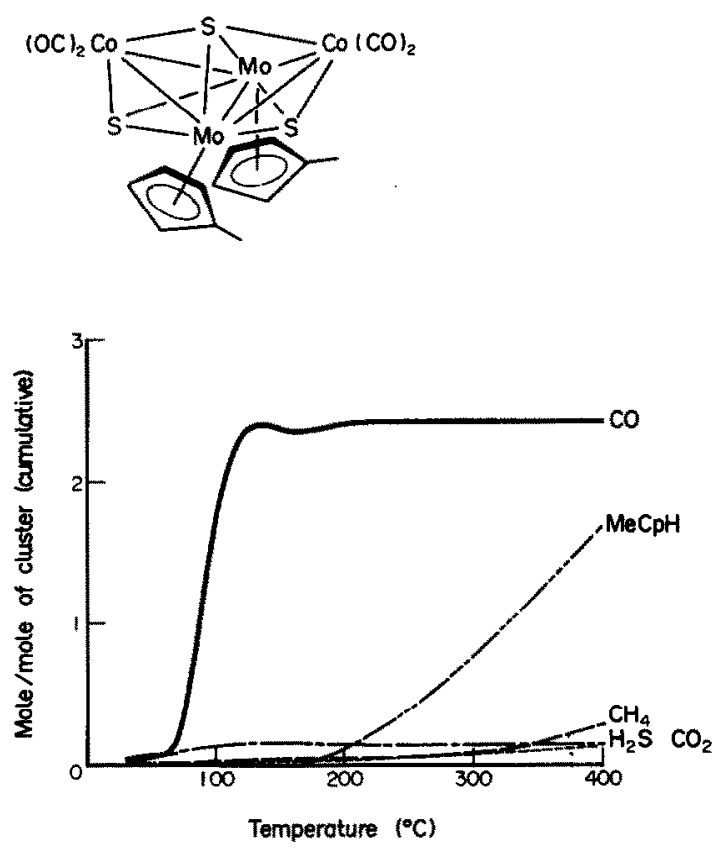

Fig. 1. Temperature programmed decomposition (TPDE) profile of $\mathrm{MoFeS} / \mathrm{SiO}_{2}$ under flowing $\mathrm{H}_{2}$.

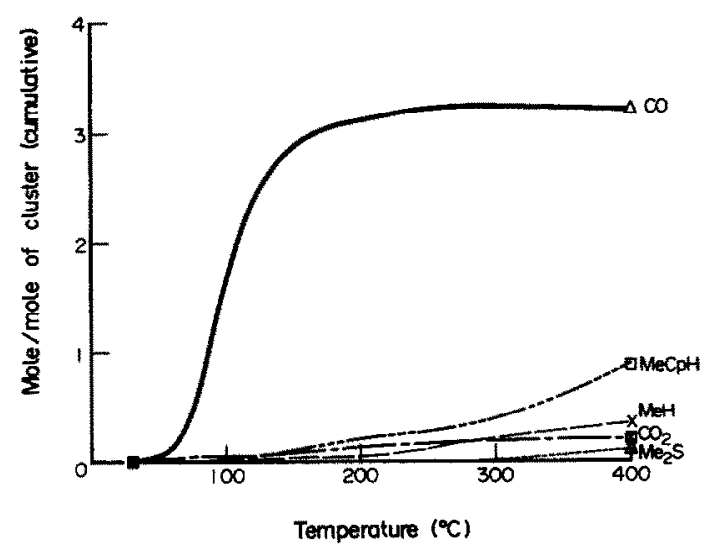

Fig. 2. TPDE profile of $\mathrm{MoFeS} / \mathrm{MgO}$ under flowing $\mathrm{H}_{2}$. 
Table 1. Number of retained carbon and sulphur atoms per adsorbed cluster following TPDE under $\mathrm{H}_{2}$ to $400^{\circ} \mathrm{C}$

\begin{tabular}{lllll}
\hline Support & $\mathrm{Al}_{2} \mathrm{O}_{3}$ & \multicolumn{1}{c}{$\mathrm{SiO}_{2}$} & $\mathrm{TiO}_{2}$ & $\mathrm{MgO}$ \\
\hline MoFeS & $\mathrm{C}_{5} \mathrm{~S}_{1.8}$ & $\mathrm{C}_{5.5} \mathrm{~S}_{1.9}$ & $\mathrm{C}_{8} \mathrm{~S}_{1.5}$ & $\mathrm{C}_{10} \mathrm{~S}_{1.8}$ \\
$\mathrm{MoCoS}$ & $\mathrm{C}_{1.7} \mathrm{~S}_{1.8}$ & $\mathrm{C}_{5.9} \mathrm{~S}_{1.4}$ & $\mathrm{C}_{8.5} \mathrm{~S}_{1.5}$ & $\mathrm{C}_{7.8} \mathrm{~S}_{1.7}$
\end{tabular}

by cleavage of the methyl group of the $\mathrm{Cp}^{\prime}$-ligand or by reduction of $\mathrm{CO}$ groups with hydrogen derived from the surface hydroxyls. Only in the case of $\mathrm{MoCoS} / \mathrm{Al}_{2} \mathrm{O}_{3}$ did the amount of evolved $\mathrm{CH}_{4}$ correspond to the amount of evolved cyclopentadiene. In most other cases, the amount of evolved methane greatly exceeded the amount of evolved $\mathrm{C}_{5} \mathrm{H}_{6}$ so that most of the methane appears to come from $\mathrm{CO}$ reduction.

The total amount of carbon retained on the surface appears to increase as the basicity of the support increases. However, the utility and significance of these TPDE curves for determining surface composition is called into question by our EXAFS results (see below).

\section{B. CO hydrogenation}

The catalytic activity toward $\mathrm{CO}$ hydrogenation of these surface compositions has been determined. Table 2 lists the turnover frequencies (mol $\mathrm{CO}$ converted/mol supported cluster-s) and product selectivities for supported MoFeS (CO hydrogenation activity for $\mathrm{MoCoS}$ is currently under investigation). The numbers in parentheses are the corresponding values when $15 \mathrm{ppm} \mathrm{H}_{2} \mathrm{~S}$ is added to the feed stream.
The data in Table 2 show that methane is the principal product (except for $\mathrm{MoFeS} / \mathrm{MgO}$, see below) and that neither the TOF nor the selectivity is affected by $15 \mathrm{ppm} \mathrm{H}_{2} \mathrm{~S}$. In contrast, $\mathrm{H}_{2} \mathrm{~S}$ acts as a severe poison for metallic catalysts. The selectivity for methane is highest for $\mathrm{MoFeS} / \mathrm{Al}_{2} \mathrm{O}_{3}$. On $\mathrm{SiO}_{2}$, about $20 \% \mathrm{C}_{2}$ (ethane + ethene) are produced along with small amounts of $\mathrm{C}_{3}+$ hydrocarbons.

$\mathrm{MoFeS} / \mathrm{MgO}$ shows an interesting transient behaviour (Figs 3 and 4). The catalyst starts by making methane almost exclusively. After a $24 \mathrm{~h}$ induction period, the activity for $\mathrm{C}_{2}$ production rapidly increases, so that at $t=25-40 \mathrm{~h}$, the product stream contains $90 \mathrm{~mol} \% \mathrm{C}_{2}$ ( $\mathrm{ca} 2: 1$ ethane : ethene). The $\mathrm{C}_{2}$-activity gradually decays and reaches an apparent steady state which contains $c a 75 \mathrm{wt} \% \mathrm{C}_{2}$ product. After $165 \mathrm{~h}$ on stream, the pressure was increased to $150 \mathrm{psig}$ (1.11 MPa) which caused the methanation activity to increase relative to the $\mathrm{C}_{2}$

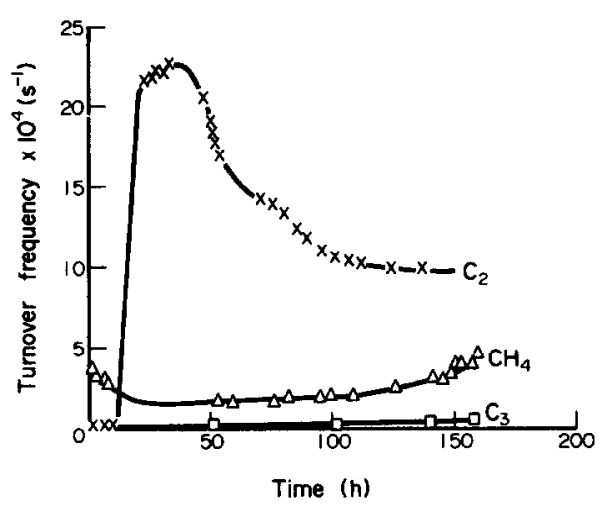

Fig. 3. Turnover frequency (mol product/mol cluster-s) for hydrogenation of $\mathrm{CO}$ over $\mathrm{MoFeS} / \mathrm{MgO}$ at $400^{\circ} \mathrm{C}$ (3: $1 \mathrm{H}_{2}: \mathrm{CO}$, total $\left.P=0.37 \mathrm{MPa}\right)$.

Table 2. Turnover frequencies ( $\mathrm{mol} \mathrm{CO} / \mathrm{mol}$ cluster-s) and product distributions for $\mathrm{CO}$ hydrogenation over $\mathrm{MoFeS} / \mathrm{Al}_{2} \mathrm{O}_{3}$ at $400^{\circ} \mathrm{C}\left(3: 1 \mathrm{H}_{2}: \mathrm{CO}\right)$

\begin{tabular}{|c|c|c|c|c|c|c|c|c|}
\hline \multirow[b]{2}{*}{ Support } & \multicolumn{4}{|c|}{$P=0.37 \mathrm{MPa}(40 \mathrm{psig})$} & \multicolumn{4}{|c|}{$P=1.11 \mathrm{MPa}(150 \mathrm{psig})$} \\
\hline & TOF $^{a}$ & $\mathrm{C}_{1}$ & $\mathrm{C}_{2}$ & $\mathrm{C}_{3+}$ & TOF & $\mathrm{C}_{1}$ & $\mathrm{C}_{2}$ & $\mathrm{C}_{3+}$ \\
\hline $\mathrm{Al}_{2} \mathrm{O}_{3}$ & $\begin{array}{c}2.6 \\
(2.5)^{b}\end{array}$ & $\begin{array}{c}98 \\
(98)\end{array}$ & $\begin{array}{c}2 \\
(2)\end{array}$ & - & $\begin{array}{c}14 \\
(12)\end{array}$ & $\begin{array}{c}96 \\
(96)\end{array}$ & $\begin{array}{c}4 \\
(4)\end{array}$ & - \\
\hline $\mathrm{SiO}_{2}$ & $\begin{array}{c}9.3 \\
(9.0)\end{array}$ & $\begin{array}{c}77 \\
(17)\end{array}$ & $\begin{array}{c}18 \\
(17)\end{array}$ & $\begin{array}{c}5 \\
(6)\end{array}$ & $\begin{array}{c}49 \\
(47)\end{array}$ & $\begin{array}{c}81 \\
(80)\end{array}$ & $\begin{array}{c}17 \\
(16)\end{array}$ & $\begin{array}{c}2 \\
(4)\end{array}$ \\
\hline $\mathrm{TiO}_{2}$ & $\begin{array}{c}34 \\
(36)\end{array}$ & $\begin{array}{c}85 \\
(87)\end{array}$ & $\begin{array}{c}11 \\
(10)\end{array}$ & $\begin{array}{c}4 \\
(3)\end{array}$ & $\begin{array}{c}148 \\
(250)\end{array}$ & $\begin{array}{c}91 \\
(86)\end{array}$ & $\begin{array}{c}9 \\
(12)\end{array}$ & $\overline{(2)}$ \\
\hline $\mathrm{MgO}$ & $\begin{array}{c}60 \\
(49)^{c}\end{array}$ & $\begin{array}{c}28 \\
(84)\end{array}$ & $\begin{array}{c}68 \\
(12)\end{array}$ & $\begin{array}{c}4 \\
(4)\end{array}$ & $\begin{array}{l}90 \\
-\end{array}$ & 56 & $\frac{34}{-}$ & $\frac{10}{-}$ \\
\hline
\end{tabular}

${ }^{a} \times 10^{4}$.

${ }^{b}$ Numbers in parentheses are with $15 \mathrm{ppm} \mathrm{H}_{2} \mathrm{~S}$ in $\mathrm{H}_{2}$.

${ }^{c}$ Measured after high pressure run. 


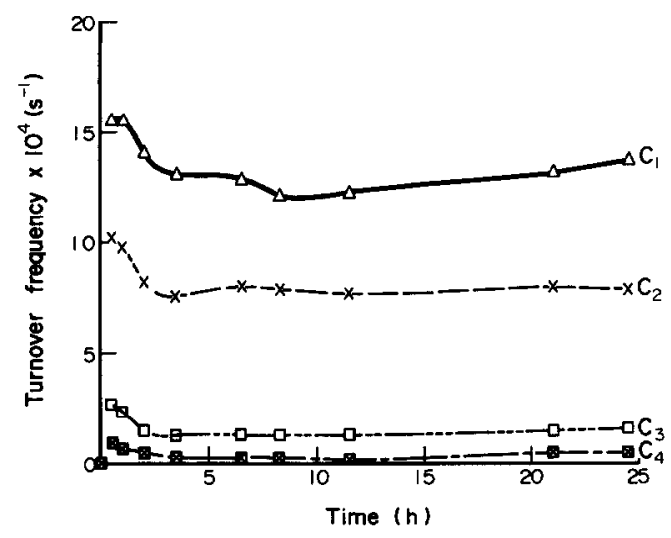

Fig. 4. Turnover frequency (mol product/mol cluster-s) for hydrogenation of $\mathrm{CO}$ over $\mathrm{MoFeS} / \mathrm{MgO}$ at $400^{\circ} \mathrm{C}$ $\left(3: 1 \mathrm{H}_{2}: \mathrm{C}\right)$, total $\left.P=1.11 \mathrm{MPa}\right)$.

activity (Fig. 4). After $25 \mathrm{~h}$ at the higher pressure, the product stream contained $56 \mathrm{~mol} \%$ methane, $34 \mathrm{~mol} \% \mathrm{C}_{2}$, and $10 \mathrm{~mol} \% \mathrm{C}_{3+}$. Decreasing the pressure to $40 \mathrm{psig}(0.37 \mathrm{MPa})$ failed to restore the high $\mathrm{C}_{2}$ selectivity; the product contained ca 85 mol $\% \mathrm{CH}_{4}$ and $10 \mathrm{~mol} \% \mathrm{C}_{2}$ (i.e. had essentially the same composition as shown in parentheses in Table 2). This behaviour clearly demonstrates that a metastable state with high $\mathrm{C}_{2}$ selectivity is initially produced, and that once the system is forced out of this metastable state, it cannot be regenerated from the final, stable state.

$\mathrm{CO}$ hydrogenation over $\mathrm{MoFeS} / \mathrm{Al}_{2} \mathrm{O}_{3}$ also shows some interesting phenomena. An initial induction period $(\mathrm{I}-2 \mathrm{~h})$ is observed, followed by a rapid rise in methanation activity. After about $10 \mathrm{~h}$ on stream, dimethyl ether begins to be produced. If the $\mathrm{CO}$ stream is interrupted, the system again repeats these induction periods when the CO stream is restored.

Figure 5 compares the product distribution obtaincd when the catalyst is pretreated under $\mathrm{H}_{2}$ or He. The change in selectivity is reversible, i.e. the

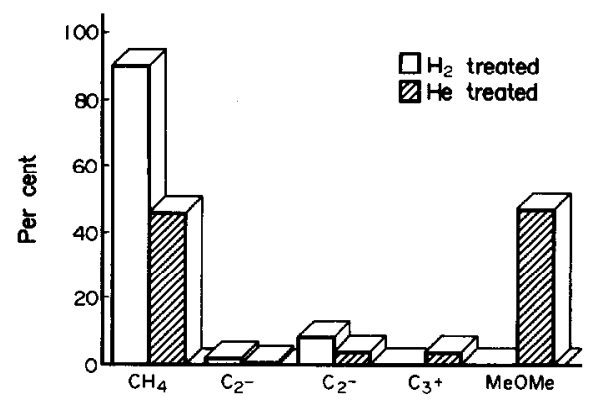

Fig. 5. Comparison of the product distribution for $\mathrm{CO}$ hydrogenation over $\mathrm{MoFeS} / \mathrm{Al}_{2} \mathrm{O}_{3}$ as a function of catalyst pretreatment $\left(3: 1 \quad \mathrm{H}_{2}: \mathrm{CO}, T=300^{\circ} \mathrm{C}, P=\right.$ $0.37 \mathrm{MPa}$ ). product distribution depends only on the immediate pretreatment, not on the catalyst history.

At no time is $\mathrm{H}_{2} \mathrm{O}$ or $\mathrm{MeOH}$ observed in the product. Therefore, we believe $\mathrm{CO}_{2}$ and $\mathrm{Me}_{2} \mathrm{O}$ are primary products, i.e. eqs (1) and (2) represent the reactions occurring.

$$
\begin{gathered}
2 \mathrm{CO}+2 \mathrm{H}_{2} \rightarrow \mathrm{CH}_{4}+\mathrm{CO}_{2} \\
3 \mathrm{CO}+3 \mathrm{H}_{2} \rightarrow \mathrm{Me}_{2} \mathrm{O}+\mathrm{CO}_{2} .
\end{gathered}
$$

The kinetics of $\mathrm{CO}$ methanation over MoFeS/ $\mathrm{Al}_{2} \mathrm{O}_{3}$ has been subjected to a Langmuir-Hinshelwood analysis. ${ }^{16}$ It was shown that the rate of formation of methane follows the rate law given in eq. (3).

$$
\begin{gathered}
\text { rate }=k \frac{K_{\mathrm{H}_{2}} K_{\mathrm{CO}} P_{\mathrm{H}_{2}} P_{\mathrm{CO}}}{\left(1+\sqrt{K_{\mathrm{H}_{2}} P_{\mathrm{H}_{2}}}+K_{\mathrm{CO}} P_{\mathrm{CO}}\right)^{2}} \\
k=3.22 \times 10^{9} \exp (-135,000 / \mathrm{R} T) \\
K_{\mathrm{H}_{2}}=2.39 \times 10^{-8} \exp (54,100 / \mathrm{R} T) \\
K_{\mathrm{CO}}=7.00 \times 10^{-6} \exp (38,200 / \mathrm{R} T) .
\end{gathered}
$$

It can be shown ${ }^{16}$ that this rate law is consistent with any Langmuir-Hinshelwood scheme in which the rate determining step contains one $\mathrm{C}$-atom and two hydrogens. In particular, the $\mathrm{CO}$ insertion mechanism or the carbide mechanism, ${ }^{17}$ with the rate determining step being either the hydrogenation of a surface formyl [eq. (4)] or the hydrogenation of a surface methylidyne [eq. (5)], respectively, with all other steps being in steady state gives rise to the observed rate law.

$$
\begin{aligned}
\mathrm{CHO}(\text { ads })+\mathrm{H}(\text { ads }) & \rightarrow \mathrm{CH}_{2} \mathrm{O} \text { (ads) } \\
\mathrm{CH}(\text { ads })+\mathrm{H}(\text { ads }) & \rightarrow \mathrm{CH}_{2} \text { (ads). }
\end{aligned}
$$

\section{HDS activity}

Table 3 shows the rates (mol thiophene converted/mol Mo-s) and product distribution observed for the hydrodesulphurization (HDS) of thiophene over $\mathrm{MoCoS} / \mathrm{Al}_{2} \mathrm{O}_{3}$ at $300{ }^{\circ} \mathrm{C}(2.7 \mathrm{~mol} \%$ thiophene in $\mathrm{H}_{2}$ at $1 \mathrm{~atm}$. pressure). Table 3 also compares these results with those obtained for a commercial catalyst (Catalco, ca $14 \% \mathrm{MoO}_{3} / 4 \% \mathrm{Co} / \mathrm{Al}_{2} \mathrm{O}_{3}$ ). Both catalysts were run in the non-sulphided form, i.e. after $\mathrm{H}_{2}$ reduction at $400^{\circ} \mathrm{C}$ ("reduced" form) and after sulphidation with $10-15 \% \mathrm{H}_{2} \mathrm{~S}$ in $\mathrm{H}_{2}$ at $400^{\circ} \mathrm{C}$. Reduced $\mathrm{MoFeS} / \mathrm{Al}_{2} \mathrm{O}_{3}$ gave results very similar to those in Table 3 . Trace amounts $(<1 \%)$ of butadiene were observed in all the catalysis runs.

Several things are apparent from the data in Table 3. First, the product distributions and activities of the $\mathrm{MoCoS} / \mathrm{Al}_{2} \mathrm{O}_{3}$ and Catalco catalysts are nearly identical at the same level of conversion. This 
Table 3. Turnover frequencies (mol thiophene converted/mol Mo-s) and product distribution for HDS of thiophene over $\mathrm{MoCoS} / \mathrm{Al}_{2} \mathrm{O}_{3}$ and a commercial catalyst $\left(2.7 \mathrm{~mol} \% \mathrm{C}_{4} \mathrm{H}_{4} \mathrm{~S}\right.$ in $\mathrm{H}_{2}$ at $\left.101 \mathrm{kPa}, T=300^{\circ} \mathrm{C}\right)$

\begin{tabular}{|c|c|c|c|c|c|c|c|c|c|c|}
\hline & Catalyst & TOF $\times 10^{4}$ & $\mathrm{CH}_{4}$ & $\mathrm{C}_{2}$ & $\mathrm{C}_{3} \mathrm{H}_{6}$ & $\mathrm{C}_{4} \mathrm{H}_{10}$ & $1-\mathrm{C}_{4} \mathrm{H}_{8}$ & cis-2- $\mathrm{C}_{4} \mathrm{H}_{8}$ & trans-2- $\mathrm{C}_{4} \mathrm{H}_{8}$ & iso- $\mathrm{C}_{4} \mathrm{H}_{8}$ \\
\hline \multirow{3}{*}{ (A) } & Reduced & & & & & & & & & \\
\hline & $\mathrm{MoCoS} / \mathrm{Al}_{2} \mathrm{O}_{3}$ & 1.5 & 3 & 13 & 37 & 1 & 6 & 10 & 12 & 18 \\
\hline & Catalco & 5.6 & 2 & 10 & 19 & 2 & 14 & 16 & 15 & 10 \\
\hline \multirow{3}{*}{ (B) } & Presulphided & & & & & & & & & \\
\hline & $\mathrm{MoCoS} / \mathrm{Al}_{2} \mathrm{O}_{3}$ & 14 & 1 & 1 & 4 & 4 & 19 & 28 & 41 & 2 \\
\hline & Catalco & 14 & 1 & 2 & 6 & 3 & 22 & 27 & 37 & 3 \\
\hline
\end{tabular}

strongly suggests that both catalysts have the same active site. Second, the cluster-derived catalyst shows a larger increase $(\times 10)$ in activity upon presulphiding than the Catalco $(\times 2.5)$. Third, the cracking activity (to propene, ethane, ethene, and methane) is much enhanced in the reduced form as compared to the sulphided form. Especially noteworthy is the relatively large amount of 2 methylpropene produced by the reduced catalysts. This product undoubtedly arises from isomerization of the butenes catalysed by acidic sites on the catalyst. Fourth, the ratios of the 1-butene: cisand trans-2-butenes approach the equilibrium values $(1: 1.73: 2.18)$, but there is always an excess of 1-butene. This suggests that 1-butene is the primary $\mathrm{C}_{4}$-product and the 2-butenes are produced from isomerization of the 1-butene.

In control experiments, 1-butene in $\mathrm{H}_{2}$ under identical conditions is isomerized to the mixture of butenes, but very little is hydrogenated and none is cracked. Butadiene, on the other hand, is hydrogenated to butenes and the amount of trans-2butene is greatly in excess of its thermodynamic value. This suggests that the primary reduction product of butadiene is trans-2-butene. Again, no cracking of butadiene is observed. In another control experiment, tetrahydrothiophene was desulphurized under the same conditions over MoCo$\mathrm{S} / \mathrm{Al}_{2} \mathrm{O}_{3}$. The products consisted of $99.6 \%$ butenes (55\% 1-butene, ca $22 \%$ each of cis- and trans-2butene) at $5 \%$ conversion.

One disturbing aspect of the product slate in Table 3 is the apparent lack of carbon balance. One would expect the amount of methane to equal the amount of propene, but this is not found (despite repeated calibration of the response factors). The balance of the carbon must be in an undetected product, e.g. MeSH, which is hidden under the large thiophene peak in the GC. Control experiments show indeed that MeSH has the same retention time as thiophene on our GC column. Mass spectral analysis of the thiophene peak is planned to detect the presence of MeSH.

\section{Mössbauer spectra}

The cluster, MoFeS, was prepared with enriched ${ }^{57} \mathrm{Fe}$ content and absorbed onto $\mathrm{Al}_{2} \mathrm{O}_{3}$. Table 4 presents the Mössbauer parameters obtained in situ. The pure, unsupported cluster shows an IS $=-0.01$ and $\mathrm{QS}=0.80 \mathrm{~mm} \mathrm{~s}^{-1}$. The supported cluster when oxidized in air shows only an $\mathrm{Fe}^{3+}$ signal with IS $=0.35$ and $\mathrm{QS}=0.98 \mathrm{~mm} \mathrm{~s}^{-1}$

The supported clusters could be taken through repeated reduction-catalysis-oxidation cycles with the result that the same Mössbauer parameters as shown in Table 4 were re-established at each appropriate point in the cycle. This result indicates that the clusters are not sintering into larger particles in the course of these cycles.

The data in Table 4 clearly show that even under $\mathrm{H}_{2}, \mathrm{H}_{2} / \mathrm{CO}$, or $\mathrm{H}_{2} /$ thiophene, the iron remains in an oxidized state ( $c a 90 \% \mathrm{Fe}^{2+}$ and $c a 10 \% \mathrm{Fe}^{\delta+}$ ). The species labelled $\mathrm{Fe}^{\delta+}$ have Mössbauer parameters characteristic of $\mathrm{Fe}$ in highly covalent, organometallic complexes, although $\mathrm{Fe}^{3+}$ (tetrahedral) can also exhibit similar parameters. ${ }^{18}$ However, the fact that this signal disappears immediately upon contact of the sample with oxygen, and reappears under $\mathrm{H}_{2}$, suggests that the signal is due to a reduced species.

It is interesting to compare these data with those obtained on conventionally prepared catalysts. Vaishnava et al. ${ }^{19}$ observed two signals with IS $=0.37$, $\mathrm{QS}=1.01$ and $\mathrm{IS}=0.35, \mathrm{QS}=0.73 \mathrm{~mm} \mathrm{~s}^{-1}$ in $\mathrm{a}$ sulphided $\mathrm{Fe} / \mathrm{Mo} / \mathrm{Al}_{2} \mathrm{O}_{3}$ sample. The first signal was attributed to a phase resembling iron aluminate in the alumina support, and the second to superparamagnetic particles of $\alpha-\mathrm{Fe}_{2} \mathrm{O}_{3}$. Topsoe et al. observed signals with parameters, IS $=0.33$, $\mathrm{QS}=1.05$ and $\mathrm{IS}=1.06, \mathrm{QS}=1.78$ in the Co emission Mössbauer spectrum of a sulphided $\mathrm{Co} / \mathrm{Mo} /$ $\mathrm{Al}_{2} \mathrm{O}_{3}$ catalyst ${ }^{20}$ which they attributed to the catalytically active $\mathrm{Co}-\mathrm{Mo}-\mathrm{S}$ phase. In view of our results and those of Vaishnava et al. it would appear that the latter signal is due to $\mathrm{Fe}^{2+}$ and the former to $\mathrm{Fe}^{3+}$. In our system, the IS $=0.3, \mathrm{QS}=1.0$ signal is 
Table 4. In situ ${ }^{57} \mathrm{Fe}$ Mössbauer parameters for $\mathrm{MeFeS} / \mathrm{Al}_{2} \mathrm{O}_{3}$ as a function of treatment

\begin{tabular}{|c|c|c|c|c|c|c|c|c|c|}
\hline \multirow[b]{2}{*}{ Conditions } & \multicolumn{3}{|c|}{$\mathrm{Fe}^{3+}$} & \multicolumn{3}{|c|}{$\mathrm{Fe}^{2+}$} & \multicolumn{3}{|c|}{$\mathrm{Fe}^{\delta+}$} \\
\hline & IS $^{a}$ & $\mathrm{QS}^{a}$ & $A \%^{b}$ & IS & QS & A\% & IS & QS & $\mathrm{A} \%$ \\
\hline $25^{\circ} \mathrm{C}$, air oxidized & 0.35 & 0.98 & 100 & - & - & - & - & - & - \\
\hline $400^{\circ} \mathrm{C}, \mathrm{H}_{2}$ & - & - & - & 1.07 & 1.86 & 90 & 0.07 & 0.31 & 10 \\
\hline $320^{\circ} \mathrm{C}, \mathrm{H}_{2} / \mathrm{CO}(3: 1)$ & - & - & - & 1.08 & 2.06 & 87 & 0.17 & 0.61 & 13 \\
\hline $25^{\circ} \mathrm{C}$, air & 0.34 & 0.98 & 95 & 1.06 & 1.95 & 5 & - & - & 一 \\
\hline $400^{\circ} \mathrm{C}, \mathrm{H}_{2}$ & - & - & - & 1.07 & 1.89 & 100 & - & - & - \\
\hline $320^{\circ} \mathrm{C}, \mathrm{H}_{2} / \mathrm{CO}(3: 1)$ & - & - & - & 1.09 & 2.07 & 93 & 0.09 & 0.44 & 7 \\
\hline
\end{tabular}

${ }^{a} \mathrm{IS}=$ isomer shift, $\mathrm{QS}=$ quadrupole splitting, both $\pm 0.05 \mathrm{~mm} \mathrm{~s}^{-1}$.

${ }^{b} \mathrm{~A} \%=$ area per cent of fitted curves.

not observed during HDS catalysis, so the species responsible for this signal are probably not involved in the catalysis.

Another conclusion from the data in Table 4 is that the surface of the cluster-derived catalyst is remarkably uniform. There appears to be only one type of surface ensemble which is entirely oxidized to a single $\mathrm{Fe}^{3+}$ species, but which is reduced to an apparent equilibrium mixture of $\mathrm{Fe}^{2+}$ and $\mathrm{Fe}^{\delta+}$. Alternatively, there are two sites $\left(90 \% \mathrm{Fe}^{2+}\right.$ and $10 \% \mathrm{Fe}^{\delta+}$ ) which, upon oxidation, give rise to a single $\mathrm{Fe}^{3+}$ environment.

\section{E. X-ray absorption spectra $(X A S)$}

XAS were obtained on $\mathrm{MoFeS} / \mathrm{Al}_{2} \mathrm{O}_{3}$ and $\mathrm{MoFeS} / \mathrm{MgO}$ with (a) no heat treatment, (b) after heating to $120^{\circ} \mathrm{C}$ under $\mathrm{H}_{2}$, and (c) after heating to $400^{\circ} \mathrm{C}$ under $\mathrm{H}_{2}$. XAS of the pure, crystalline cluster were also obtained. Figures 6 and 7 show the near edge structure (XANES) of the Fe and Mo edges and Figs 8 and 9 are the Fourier transforms (phase

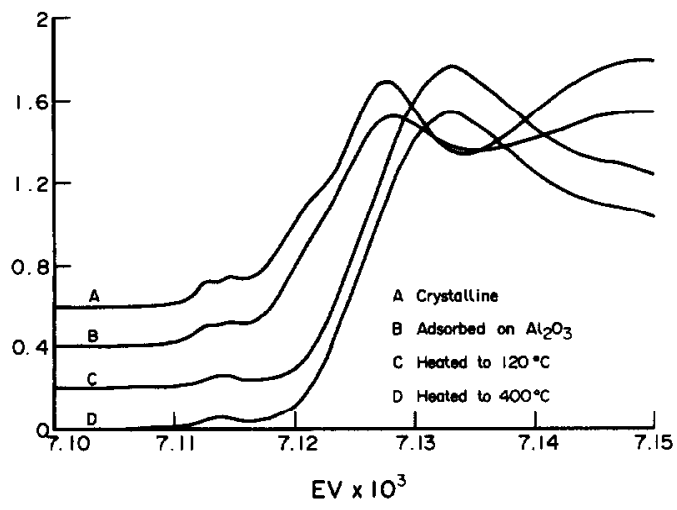

Fig. 6. Fe-XANES spectrum of $\mathrm{MoFeS}$ and $\mathrm{MoFeS} /$ $\mathrm{Al}_{2} \mathrm{O}_{3}$. (A) Pure crystalline cluster, (B) cluster on $\mathrm{Al}_{2} \mathrm{O}_{3}$ with no heat treatment, $(\mathrm{C})$ on $\mathrm{Al}_{2} \mathrm{O}_{3}$ after heating to $120^{\circ} \mathrm{C}$ under $\mathrm{H}_{2}$, (D) on $\mathrm{Al}_{2} \mathrm{O}_{3}$ after heating to $400^{\circ} \mathrm{C}$ under $\mathrm{H}_{2}$.

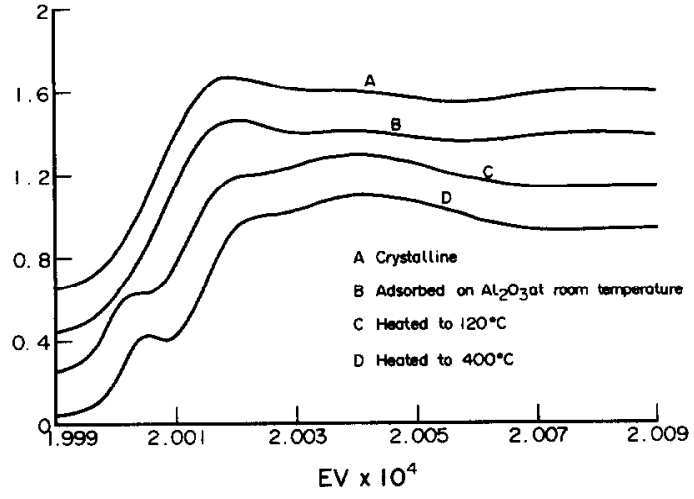

Fig. 7. Mo-XANES spectrum of MoFeS and MoFeS on $\mathrm{Al}_{2} \mathrm{O}_{3}$. Labels (A)-(D) are as in Fig. 6.

shifted radial distribution functions) of the $\mathrm{Fe}$ and Mo EXAFS, respectively, for $\mathrm{MoFeS} / \mathrm{Al}_{2} \mathrm{O}_{3}$.

The Fe-XANES of the pure cluster and the cluster adsorbed on $\mathrm{Al}_{2} \mathrm{O}_{3}$ at room temperature (Fig. 6) are very similar. Both occur at essentially the same energy and both exhibit a pre-edge feature associated with a $1 s-3 d$ transition. The spectra of the two heated samples are identical and are shifted $c a 5 \mathrm{eV}$ to higher energies, an indication that the iron is now in a higher oxidation state. The preedge feature loses its structure, suggesting a more symmetrical arrangement of ligands about the iron.

Similar conclusions follow from the Mo-XANES (Fig. 7). The spectra of the pure cluster and the cluster on $\mathrm{Al}_{2} \mathrm{O}_{3}$ at $25^{\circ} \mathrm{C}$ are identical. Thus, the cluster is initially absorbed with essentially no change in the immediate environment of the Moatoms. The spectra of the samples heated to 120 and $400^{\circ} \mathrm{C}$ under $\mathrm{H}_{2}$ are nearly identical but different from the first two. The edges are shifted $c a 5 \mathrm{eV}$ to higher energies and a pre-edge feature appears which is attributed to the presence of one or more Mo $=0$ bonds.

The phase-shifted radial distribution function (RDF) derived from the Fe-EXAFS (Fig. 8) shows 


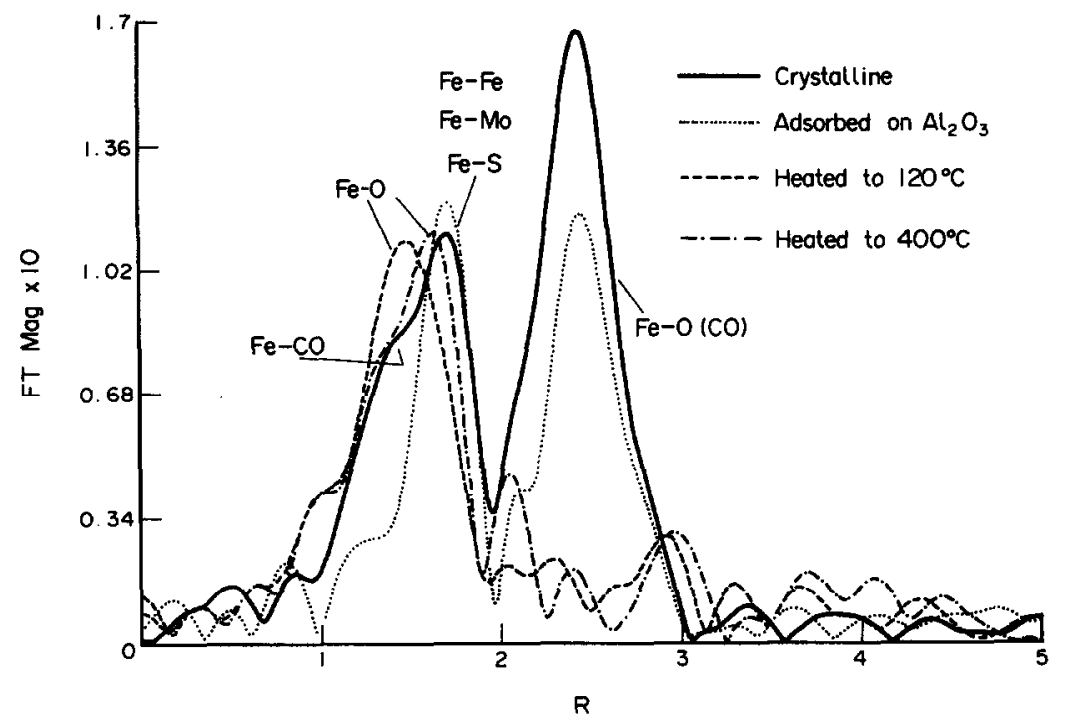

Fig. 8. Fourier transforms of Fe-EXAFS of $\mathrm{MoFeS}$ and $\mathrm{MoFeS} / \mathrm{Al}_{2} \mathrm{O}_{3}$.

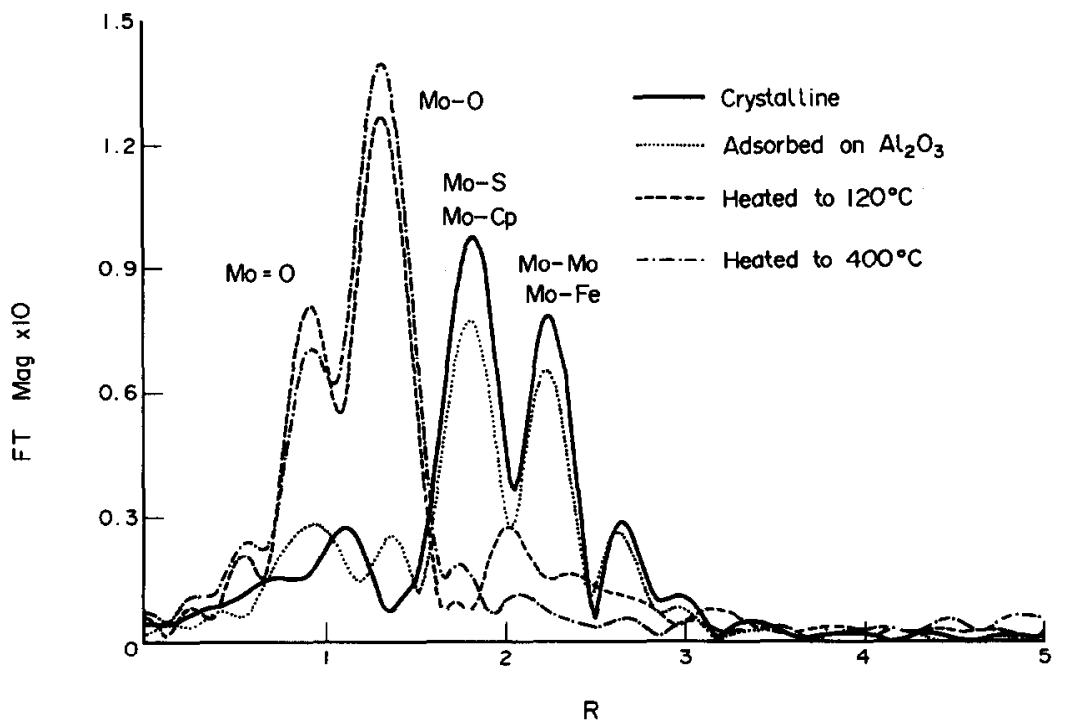

Fig. 9. Fourier transforms of Mo-EXAFS of $\mathrm{MoFeS}$ and $\mathrm{MoFeS} / \mathrm{Al}_{2} \mathrm{O}_{3}$.

two major peaks for the pure cluster. The first peak, with a shoulder at low $\mathrm{R}$, corresponds to the unresolved $\mathrm{Fe}-\mathrm{S}, \mathrm{Fe}-\mathrm{Fe}$, and $\mathrm{Fe}-\mathrm{Mo}$ distances (2.3$2.8 \AA$ from the single crystal structure). Upon absorption on $\mathrm{Al}_{2} \mathrm{O}_{3}$, the peaks associated with the $\mathrm{Fe}-\mathrm{CO}$ distances decrease in intensity. Curve fitting shows the adsorbed cluster has lost approximately $1.5-2 \mathrm{CO}$ groups per $\mathrm{Fe}$.

Upon heating to $120^{\circ} \mathrm{C}$ under $\mathrm{H}_{2}$, all these peaks are lost and a new peak corresponding to $\mathrm{Fe}-\mathrm{O}$ appears. Further heating the sample to $400^{\circ} \mathrm{C}$ causes a small change in the shape and position of this peak, but curve fitting shows both spectra can be fitted with six oxygen atoms at a distance of 1.95 $\AA$ from the Fe.
The environment around the Mo is revealed from the RDFs in Fig. 9. Both the pure crystalline cluster and the cluster adsorbed on $\mathrm{Al}_{2} \mathrm{O}_{3}$ show two peaks. The first is associated with $\mathrm{Mo}-\mathrm{S}$ and $\mathrm{Mo}-\mathrm{C}(\mathrm{Cp})$ (true distance $c a 2.3 \AA$ ), and the second with $\mathrm{Me}-\mathrm{Fe}$ and $\mathrm{Mo}-\mathrm{Mo}$ vectors (true distance $\mathrm{ca}$ $2.8 \AA$ ). These peaks are replaced by Mo-O peaks when the sample is heated to 120 or $400^{\circ} \mathrm{C}$ under $\mathrm{H}_{2}$.

Thus, the EXAFS and XANES spectra show that upon heating under $\mathrm{H}_{2}$, both $\mathrm{Fe}$ and $\mathrm{Mo}$ are oxidized by the surface (most likely by the surface hydroxyl groups) to give oxide surface complexes. These results agree with the Mössbauer results which showed oxidation of the Fe to predominately 
$\mathrm{Fe}^{2+}$ on the surface under actual working conditions. Furthermore, essentially all the oxidation/ decomposition reactions are complete by $120^{\circ} \mathrm{C}$. This picture contrasts with the TPDE results which show continuing evolution of hydrocarbon ligands from 180 to $400^{\circ} \mathrm{C}$. It would appear that the cluster is oxidized at $\leqslant 120^{\circ} \mathrm{C}$ and releases the hydrocarbon to the alumina surface. The TPDE experiment is then a measure of the activation energies required to release the hydrocarbon from the surface and is not a good indicator of cluster decomposition per se.

Preliminary EXAFS results obtained for $\mathrm{MoFeS} / \mathrm{MgO}$ show much the same behaviour as for $\mathrm{MoFeS} / \mathrm{Al}_{2} \mathrm{O}_{3}$. The major differences are that decomposition of the clusters already occurs at room temperature to give the surface oxo species and that long range order reappears in the EXAFS as the sample is heated under $\mathrm{H}_{2}$ to $400^{\circ} \mathrm{C}$. These data are currently under analysis, but preliminary results show the new long range order is not due to elemental iron or simple iron oxides.

\section{F. Mechanistic conclusions}

(a) $\mathrm{CO}$ hydrogenation. The combination of the product distribution, kinetics, and the Mössbauer and EXAFS characterization suggest that the active sites for $\mathrm{CO}$ hydrogenation activity of these clusters supported on metal oxides are surface oxoensembles. None of the data collected to date allows us to establish the structure of these surface ensembles, but it is clear that the "promoter", $\mathrm{Fe}$ or $\mathrm{Co}$, plays an important role in defining the activity of these sites. On the basis of the data in hand, we propose the general mechanism shown in Scheme 1 for the production of $\mathrm{CH}_{4}, \mathrm{Me}_{2} \mathrm{O}$, and $\mathrm{CO}_{2}$ over these oxo-surface ensembles.

In this scheme, " $M$ " represents the surface ensemble and may consist of more than a single metal atom. The resting state of the catalyst is proposed to be a metal oxo species, and is the most abundant species on the surface. This accounts for the fact that only minor changes in the Mössbauer parameters are seen in situ as the gas phase is changed from pure $\mathrm{H}_{2}$ to $\mathrm{H}_{2} / \mathrm{CO}$.

The $\mathrm{CO}$ reacts with the oxo-ensemble to produce $\mathrm{CO}_{2}$ (a primary product) with concomitant reduction in the oxidation state of the ensemble by two units [eg. $\mathrm{Mo}(\mathrm{VI}) \rightarrow \mathrm{Mo}(\mathrm{IV})$ or $\mathrm{Mo}(\mathrm{V}) \rightarrow$ $\mathrm{Mo}(\mathrm{III})]$. Additional $\mathrm{CO}$ and $\mathrm{H}_{2}$ then binds to the reduced ensemble. Insertion of the $\mathrm{CO}$ into an $\mathrm{M}-\mathrm{H}$ bond leads to a surface formyl species which

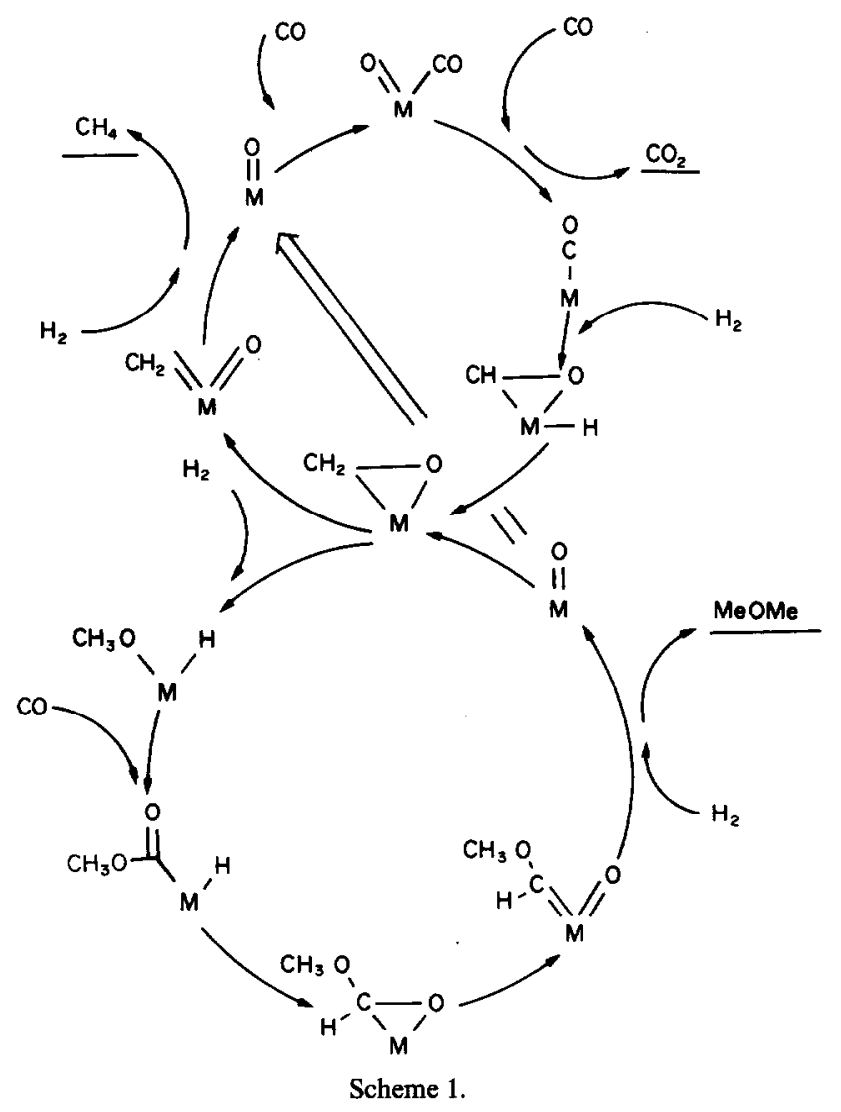


is hydrogenated to an adsorbed formaldehyde in the rate determining step. The surface formaldehyde may follow either of two reaction pathways : in path 1 (top circle, Scheme 1), this species is cleaved to a surface oxo-methylidene for which there are organometallic precedents. ${ }^{21}$ The surface methylidenes may couple and lead to higher hydrocarbons, or be hydrogenated to methane to regenerate the resting state of the catalyst.

In path 2 (lower circle, Scheme 1), the surface formaldehyde is hydrogenated to bound methoxide. Absorbed $\mathrm{CO}$ then inserts into the $\mathrm{M}-\mathrm{OMe}$ bond to produce a metalla-ester which is hydrogenated to a methoxyformyl. This formyl is then cleaved as in path 1 to an oxo-methoxymethylene which, upon hydrogenation, gives dimethyl ether (a primary product) and restores the resting state $(\mathrm{M}=\mathrm{O})$. Subtle changes in the surface induced by the pretreatment $\left(\mathrm{H}_{2}\right.$ or $\left.\mathrm{He}\right)$ change the relative amounts of branching between the two pathways (cf. Fig. 5).

(b) HDS of thiophene. The Mössbauer parameters show that the catalyst surface changes very little when a stream of $\mathbf{H}_{2}$ is replaced with a stream of $\mathrm{H}_{2}+2.7 \%$ thiophene at $300^{\circ} \mathrm{C}$. Under these conditions, the thiophene is desulphurized (checked by analysing the exit gases from the Mössbauer cell). The EXAFS shows that the predominant surface species under these conditions are metal oxo complexes. Therefore, $\mathrm{MoS}_{2}$-like domains are not a necessary prerequisite for significant HDS activity of supported Mo HDS catalysts.

It is also interesting to note that neither the thiophene nor the small concentration $(\leqslant 0.05 \%)$ of $\mathrm{H}_{2} \mathrm{~S}$ produced in the differential flow reactor is capable of "sulphiding" the catalyst. Reactivity changes are noted when the catalysts are presulphided with much higher concentrations (10$15 \%$ ) of $\mathrm{H}_{2} \mathrm{~S}$, however (see Table 3). We are currently collecting Mössbauer and EXAFS data on the supported clusters which have been presulphided with $\mathrm{H}_{2} \mathrm{~S}$ in order to determine the effect of pre-sulphiding on the structure of the surface ensembles.

Some interesting conclusions may be drawn from the HDS product distribution when combined with the control experiments with 1-butene and butadiene. Since significant amounts of $\mathrm{C}_{1}, \mathrm{C}_{2}$, and $\mathrm{C}_{3}$ hydrocarbons are produced during thiophene HDS, but none of these products is detected when 1butene or butadiene is passed over the catalyst, it follows that the cracking must occur while the sulphur is still attached to the $\mathrm{C}_{4}$ fragment. Furthermore, the fact that butadiene is rapidly hydrogenated to butenes, but the butenes are hydrogenated slowly, suggests an $\eta^{4}$-coordination for the butadiene, which in turn implicates a $\pi$-bound thiophene in the HDS reaction.

Angelici and coworkers ${ }^{22}$ have recently reported the synthesis of $\eta^{5}$-thiophene metal complexes and have presented model reactions of these complexes which implicate $\pi$-bound thiophene in the HDS catalysis. Furthermore, their data show that 2,3dihydrothiophene is a likely intermediate in the HDS of thiophene.

Taken together, our data on the reactions of thiophene, tetrahydrothiophene, 1-butene, and 1,3butadiene over $\mathrm{MoCoS} / \mathrm{Al}_{2} \mathrm{O}_{3}$ suggest the mechanisms in Scheme 2.

The essentially complete conversion of tetrahydrothiophene (THT) to butenes at low conversion suggests that at least one of the desulphurization steps occurs by a " $\beta$-elimination" mechanism (Scheme (2a)). Butenes are also produced when THT is desorbed from an Mo(100) surface. ${ }^{23}$ The fact that only traces $(<1 \%)$ of methane, ethene, and propene are formed in the HDS of THT eliminates THT as an intermediate to these species in the HDS of thiophene. We therefore propose that thiophene is first hydrogenated to dihydrothiophenes which can then enter any of several reaction channels as shown in Scheme (2a). The adsorbed 2,5-dihydrothiophene (1) is the likely intermediate to butadiene. ${ }^{22}$ Since so little butadiene is formed, the major route is apparently through the 2,3-isomer (2).

Adsorbed 2 is proposed to undergo $\mathrm{C}-\mathrm{C}$ bond cleavage via 3 to eventually produce propene, methane, and methanethiol. Insertion into the $\mathrm{C}-\mathrm{S}$ bond of 2 could give intermediate 4 which leads to butene as the major product through intermediate 5. An alternate minor path can lead to butenes or a metallacyclopentane 6 . Intermediate 6 could scission by well documented pathways ${ }^{24}$ to butene or to ethylene.

Clearly there is insufficient data to justify all the steps in Scheme 2. However, these were drawn so as to incorporate reasonable steps well known in organometallic chemistry which lead to the observed products. Current experiments are aimed at testing some of the proposed steps in Scheme 2.

\section{SUMMARY}

The results obtained to date show that sulphido bimetallic clusters are excellent precursors for the formation of uniform catalytic surfaces. The uniformity of the surface species facilitates physical characterization of the active site(s). Our results show that the supported clusters are transformed to surface oxo-ensembles which are active for 
(a) HDS of tetrohydrothiophene

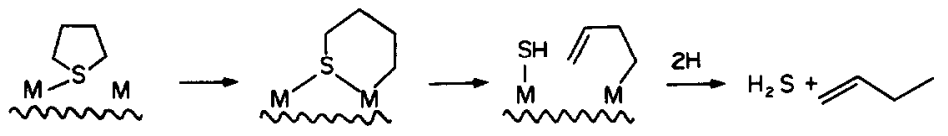

(b) HDS of thiophene
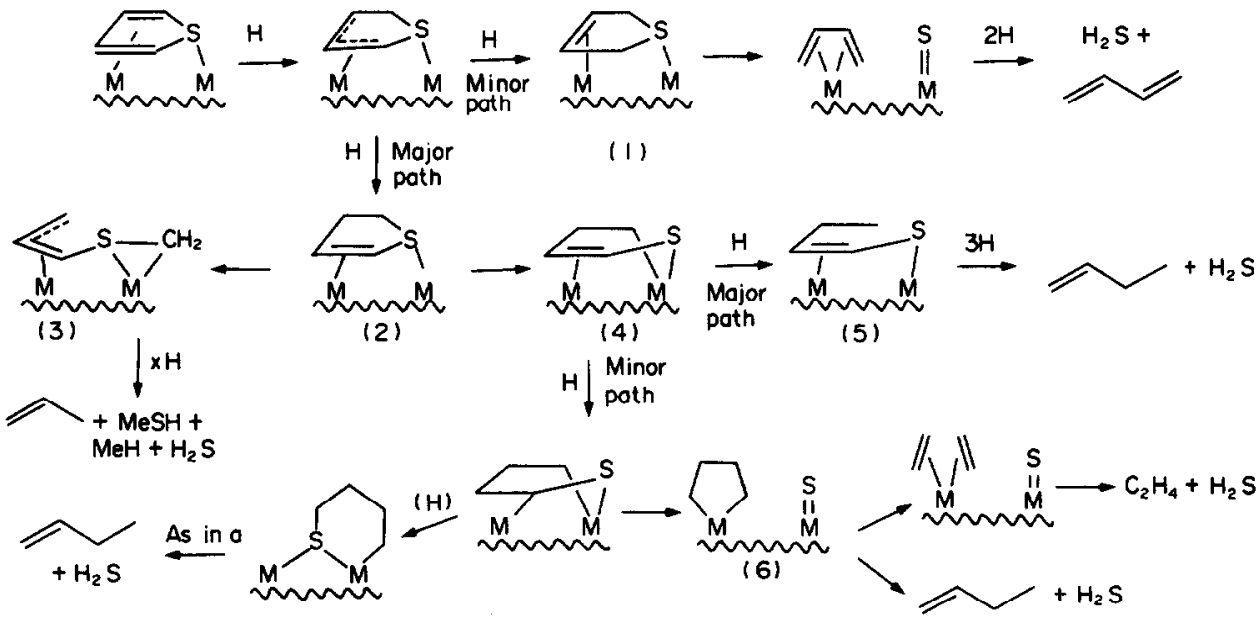

Scheme 2.

CO hydrogenation and HDS of organic sulphur compounds.

\section{REFERENCES}

1. (a) Y. Iwasawa and M. Yamagishi, J. Catal. 1983, 82, 373; (b) Y. Iwasawa, Y. Sato and H. Kuroda, ibid. 289.

2. O. Leal, M. R. Goldwasser, H. Martinez, M. Garmendia, R. Lopez and H. Arzoumanian, J. Molec. Catal. 1983, 22, 117.

3. (a) A. F. Danilyuk, V. L. Kuznetsof and Y. I. Ermakov, Kinet. Katal. 1983, 24, 926 ; (b) A. Brenner and R. L. Burwell Jr., J. Catal. 1978, 52, 364.

4. R. Nakamura, R. G. Bowman and R. L. Burwell Jr., J. Am. Chem. Soc. 1981, 103, 673.

5. P. Braunstein, R. Bender and J. Kervenal, Organometallics 1982, 1, 1236.

6. M. Ichikawa, J. Catal. 1979, 59, 67.

7. J. Zwart and R. Snel, J. Molec. Catal. 1985, 30, 305.

8. Yu I. Yermakov, J. Molec. Catal. 1983, 21, 35.

9. J. M. Basset and A. Choplin, J. Molec. Catal. 1983, 21, 95 .

10. R. Ugo and R. Psaro, J. Molec. Catal. 1983, 20, 53.

11. D. C. Bailey and S. H. Langer, Chem. Rev. 1981, 81, 109.

12. E. L. Meutterties and M. J. Krause, Angew. Chem., Int. Ed. Engl. 1983, 95, 135.
13. Y. Iwasawa (Ed.), Tailored Metal Catalysts. D. Reidel, Boston, MA (1986).

14. Yu I. Yermakov, B. N. Kuznetsov and V. A. Zakharov, Catalysis by Supported Complexes. Elsevier, Amsterdam (1981).

15. (a) P. D. Williams, M. D. Curtis, D. N. Duffy and W. M. Butler, Organometallics 1983, 2, 165; (b) M. D. Curtis and P. D. Williams, Inorg. Chem. 1983, 22, 2661.

16. L. T. Thompson Jr., J. Schwank and M. D. Curtis, submitted to J. Catal. (1988).

17. C. Masters, Adv. Organomet. Chem. 1979, 17, 61.

18. C. Wivel, B. S. Clausen, R. Candia, S. Morup and H. Topsoe, J. Catal. 1984, 87, 497.

19. P. P. Vaishnava, P. A. Montano, R. E. Tischer and S. S. Pollack, J. Catal. 1982, 78, 454.

20. H. Topsoe, B. S. Clausen, R. Candia, C. Wivel and S. Morup, J. Catal. 1981, 68, 433.

21. J. H. Wengrovius and R. R. Schrock, Organomtallics $1982,1,148$.

22. (a) A. Lesch, J. W. Richardson Jr., R. A. Jacobson and R. J. Angelici, J. Am. Chem. Soc. 1984, 106, 2901 ; (b) G. H. Spies and R. J. Angelici, ibid. 1985, $107,5569$.

23. J. T. Roberts and C. M. Friend, J. Am. Chem. Soc. 1986, 108, 7204.

24. (a) J. D. Fellmann, G. A. Rupprecht and R. R. Schrock, J. Am. Chem. Soc. 1979, 101, 5099; (b) J. X. McDermott and G. M. Whitesides, ibid. 1976, 98, 6521; (c) R. H. Grubbs, A. Miyashita, M. Liu and P. Burk, ibid. 1978, 100, 2418. 